\title{
Analysis of Association between Posterior Crossbite, Median Line Deviation and Facial Asymmetry
}

\author{
Análisis de La Asociación entre Mordida Cruzada Posterior, \\ Desviación de la Línea Mediana y Asimetría Facial
}

Santos, R. R. ; Garbin, A. J. I.**; Saliba, O.** \& Garbin, C. A. S..***

SANTOS, R. R.; GARBIN, A. J. I.; SALIBA, O. \& GARBIN, C. A. S. Analysis of association between posterior crossbite, median line deviation and facial asymmetry. Int. J. Odontostomat., 8(1):93-97, 2014.

ABSTRACT: Facial asymmetry is a common human characteristic and can occur on many levels, originate of genetic factors, and can be caused by traumas or due to cross bite and/or muscular disability. The aim of this study was to evaluate the relation between posterior crossbite, median line deviation and facial asymmetry. For this study 70 children aged between 3 and 10 years-old were examined and photographed. Using Microsoft Office Power Point 2007, horizontal lines and one vertical line on median line were drawn, to subjectively analyze facial discrepancies. In relation to overjet, the majority of children (78.6\%) showed normal relation, followed by high overjet (17.1\%), anterior crossbite (4.3\%). In relation to overbite, the majority of children (60\%) showed normal relation, $27.1 \%$ anterior opened bite (negative overbite), and $12.9 \%$ showed high overbite. Posterior crossbite was present in $27.1 \%$ of children. Among them, $68.4 \%$ showed unilateral crossbite on right side, $21.1 \%$ bilateral crossbite and $10.5 \%$ unilateral crossbite on left side. The relation between posterior crossbite and facial asymmetry, according to Fisher's Exact Test $(p=0.0970)$, there was no statistically significant association. In relation to median line, the association was statistically significant with posterior crossbite $(p=0.0109)$ and with facial asymmetry $(p=0.0310)$. There was association between posterior crossbite and median line deviation. There was no association between posterior crossbite and facial asymmetry.

KEY WORDS: facial asymmetry, crossbite, malocclusion, orthodontics.

\section{INTRODUCTION}

Facial asymmetry is a phenomenon that occurs naturally, and in the majority of cases, can be observed only through comparison between homologue parts of the face. Analyzing the physical form of facial tissues, allows verifying the asymmetry with skeletal component or not (Almeida et al., 2009). It is a common human characteristic and can occur on many levels, origins of genetic factors; it can be caused by traumas or cross bite and/or muscular disability (Dalla-Bona et al., 2005).

Posterior crossbite is considered as an abnormal dental relation on buccal-lingual direction when the occlusion of arches occurs (Almeida et al.) and is a high prevalence alteration (Primozic et al., 2009) It can lead to bone base dystrophy, with orthopedic or structural alterations, resulting in facial asymmetries (Gribel, 1999; Gonçalves et al., 2007; Castelo et al., 2010).

In every malocclusion, the crossbite has a multifactor etiology, with the influence of genetic and environmental factors, and the interaction among themselves (Primozic et al.). The asymmetries between the two sides of inferior maxillary is normally consequence of mandibular adaptive response during function deviation, and can cause condylar remodeling.

Doctor Degree Candidate in Post-graduation Program in Preventive and Social Dentistry, Araçatuba Dental School, UNESP, Univ. Estadual Paulista, Araçatuba, Brazil.

** Assistant Professor of Post-graduation Program in Preventive and Social Dentistry, Araçatuba Dental School, UNESP, Univ. Estadual Paulista, Araçatuba, Brazil.

*** Full Professor, Post-graduation Program in Preventive and Social Dentistry, Araçatuba Dental School, UNESP, Univ. Estadual Paulista, Araçatuba, Brazil.

**** Assistant Professor and Vice-Coordinator of Post-graduation Program in Preventive and Social Dentistry, Araçatuba Dental School, UNESP, Univ. Estadual Paulista, Araçatuba, Brazil. 
The prevalence and severity of mandibular asymmetries on mixed and deciduous dentition has been studied to some extent; however, early identification and orthodontic treatment contribute to improving dental and skeletal development. The perpetuation of wrong function on initial phases causes principally transversal discrepancies, and can result in problems in temporomandibular articulation.

Recently, the relation between occlusion and posture has been noted by researchers. In dentistry and orthopedic surgery many investigations have been carried out, demonstrating the relation between cervical curvature and facial morphology (Gazit-Rappaport et al., 2007). Pathological alterations can lead to motor problems and influence posture. When the posture becomes perturbed, some changes in articulations and muscle tone occurs which can modify motor and postural function (Domiciano et al., 2010).

Any postural misadjustments, trauma on structures linked to cranium, mandibular maxillary, occlusion, vertebral column, stern bone and scapular can modified the condition of muscles and bones responsible for orthostatic position, modifying the axial axis and thus modify the equilibrium and orientation of individual. These changes are expressed through asymmetries.

The aim of this study was to verify the existence of correlation between posterior crossbite, median line deviation and facial asymmetry using frontal, intra and extra photos.

\section{MATERIAL AND METHOD}

The presente study was performed after aproval of the Ethical Committee on Research with Human of Araçatuba Denta School - São Paulo State University/ UNESP, and has therefore been performed in accordance with the ethical standards established in the 1975 Declaration of Helsinki and its later amendments. After signature of clear and free consent term of responsible adult or the parents of participants.

The research was performed in the city of Araçatuba and 70 children between 3 and 10 years of age were examined and photographed.

On clinical exam the overjet and overbite was verified, as was the presence of posterior crossbite.
On children with deciduous dentition the type of arch was verified, according Baume's classification (Baume, 1950) and the terminal plan of second molar.

The photos were taken with digital camera (PowerShot A495). Photos of intra and extrabucal of the subjects were taken, with subjects standing in a confortable position, not forcing the posture, looking forward and with a relaxed labial posture (Fig. 1).

Using the Microsoft Office Power Point 2007 Program, horizontal lines were drawn from pupil center to the higher point of the shoulder, passing for ear base. The right side was chosen as the preferred side. A vertical line on median line was drawn to analize facial discrepancies.

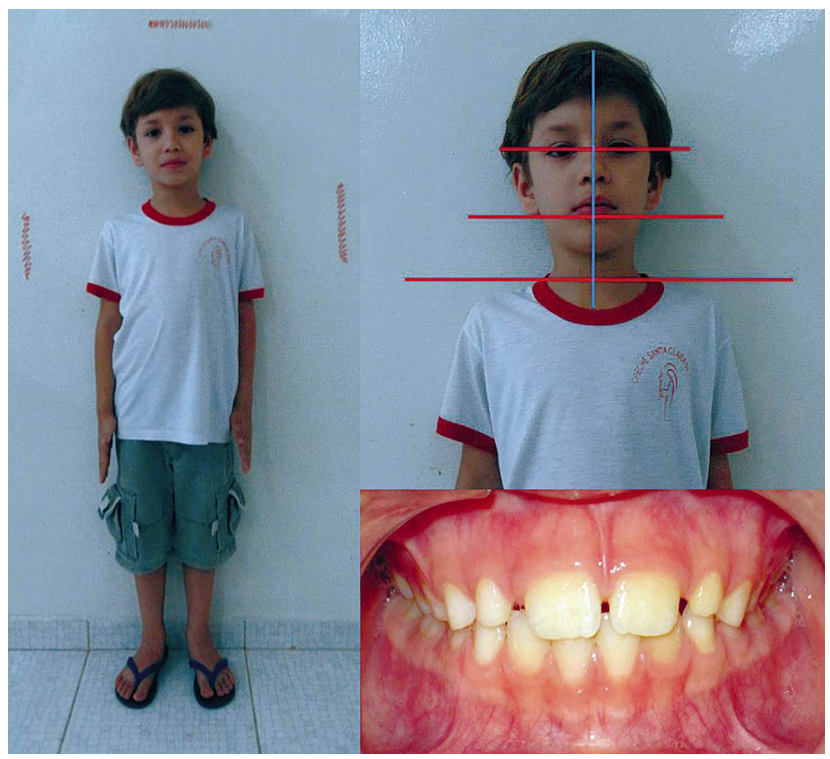

Fig. 1. Photos of intra and extrabucal of the subjects, with subjects standing in a confortable position, not forcing the posture, looking forward and with a relaxed labial posture.

\section{RESULTS}

In reference to sex of the population studied, it was possible to verify that among $70(100 \%)$ evaluated children, 36 were girls and 34 were boys. Median age was 4.4 years.

In relation to overjet, a great number of children $(78.6 \%)$ showed normal relation, $17.1 \%$ high overjet, $4.3 \%$ anterior crossbite. The majority of children (60\%) showed normal overbite, $27.1 \%$ opened bite and $12.9 \%$ showed high overbite. 
On individuals with completed deciduous dentition $(n=65)$ the type of arch and terminal plan was evaluated, and it was possible to observe that arch type I and distal terminal plan were the most prevalent.

Posterior crossbite was present in $27.1 \%$ of children and among these, $68.4 \%$ showed unilateral crossbite on right side, $21.1 \%$ bilateral crossbite and $10.5 \%$ unilateral crossbite on left side. After photographic analysis it was possible to verify that $24.3 \%$ showed median line deviation and $82.8 \%$ showed facial asymmetry.

The relation between posterior crossbite and facial asymmetry (Table I), according to analysis by Fisher's Test $(p=0.0970)$, it was not statistically significant. In relation to median line, there was statistically significant association with posterior crossbite $(p=0.0109)$ (Table II), and also with facial asymmetry $(p=0.0310)$ (Table III).

Table II. Association between median line deviation and posterior crossbite.

\begin{tabular}{lccc}
\hline \multirow{2}{*}{ Asymmetry } & \multicolumn{2}{c}{ Crossbite } & \multirow{2}{*}{ Total } \\
\cline { 2 - 3 } & Present & Not present & \\
\hline Present & 18 & 1 & $\mathbf{1 9}$ \\
Not present & 39 & 12 & $\mathbf{5 1}$ \\
Total & $\mathbf{5 7}$ & $\mathbf{1 3}$ & $\mathbf{7 0}$
\end{tabular}

*Fisher's Exact Test

$p=0.0970 \quad$ Not significative

Table I. Association between facial asymmetry and posterior crossbite.

\begin{tabular}{lccc}
\hline \multirow{2}{*}{ Median Line } & \multicolumn{2}{c}{ Crossbite } & \multirow{2}{*}{ Total } \\
\cline { 2 - 3 } & Present & Not present & \\
\hline Not centralized & 9 & 8 & 17 \\
Centralized & 10 & 43 & $\mathbf{5 3}$ \\
Total & 19 & $\mathbf{5 1}$ & $\mathbf{7 0}$ \\
*Fisher's Exact Test & & \\
$\mathrm{p}=0.0109$ & \multicolumn{2}{c}{ Significative } \\
\hline
\end{tabular}

Table III. Association between median line deviation and facial asymmetry.

\begin{tabular}{lccc}
\hline \multirow{2}{*}{ Median Line } & \multicolumn{2}{c}{ Asymmetry } & \multirow{2}{*}{ Total } \\
\cline { 2 - 3 } & Present & Not Present & \\
\hline Centralized & 41 & 12 & $\mathbf{5 3}$ \\
Not centralized & 17 & 0 & $\mathbf{1 7}$ \\
Total & $\mathbf{5 8}$ & $\mathbf{1 2}$ & $\mathbf{7 0}$ \\
*Fisher's Exact Test & & & \\
p $=0.0310$ & \multicolumn{2}{c}{ Significative } & \\
\hline
\end{tabular}

\section{DISCUSSION}

In dentistry, particularly in orthodontia, the principal aim is get a good occlusion, with anterior-posterior equilibrium. However, patients with some mandibular deviation that are subject to orthodontic treatment not only get back axis-mandibular equilibrium, but also experience skeletal corrections.

The results of this study in relation to overjet, reflates the results found on literature (Martins et al., 2003; Oliveira, 2004; Kataoka et al., 2006).

Macena et al. (2009) found in their study, that the prevalence of posterior crossbite was $10.4 \%$ in children. This prevalence is lower than the results of this study, but it is similar when we observe that unilateral crossbite occurred on the right side. Analyzing the relation between facial asymmetry and posterior crossbite it was not possible to find statistically significant association $(p=0.1263)$. The studies about the theme show many divergences in results and methods used.

In relation to measures between face segments, the children with crossbite showed dimensional and proportional discrepancy (Primozic et al.; Castelo et al.) when they were compared with children that showed normal occlusion. In the present study there was facial asymmetry in children that presented crossbite and those that presented normal occlusion.

The importance on early detection of crossbite allows the possibility for correction of facial asymmetry when the malocclusion treatment occurs on deciduous dentition, principally on inferior third of face (Primozic et al.), and contributes to favorable muscle-skeletal development avoiding bone bases dystrophies (Gribel). Other factors to point out is that treatment in adults consists principally of surgical repositioning in maxilla and mandible(Guyuron, 1989; Bardinet et al., 2002; Proffit et al., 2003).

Gazit-rappaport et al. $(2003,2007)$ showed that the correction of unilateral anterior crossbite caused by functional deviation restored labial asymmetry in young patients, visual and quantitatively, even without an approach of skeletal asymmetry.

Using tridimensional models of finite elements, Shimazaki et al. (2003) observed that lateral inclination of oclusal plan, causes the disequilibrium between right and left side of masticatory muscles that act on deviation of the cervical spine. 
The asymmetry may only be of skeletal origin, with or without an element of mandibular deviation. A lengthy study would be necessary to explore the diverse factors (Good et al., 2006) and standardize the methods used, in order to realize a comparison among the different studies and populations.
CONCLUSION. There was association between posterior crossbite and median line deviation and between median line deviation and facial asymmetry. There was no association between posterior crossbite and facial asymmetry. Longitudinal studies with a larger sample and with older children are suggested.

SANTOS, R. R.; GARBIN, A. J. I.; SALIBA, O. \& GARBIN, C. A. S. Análisis de la asociación entre mordida cruzada posterior, desviación de la línea mediana y asimetría facial. Int. J. Odontostomat., 8(1):93-97, 2014.

RESUMEN: La asimetría facial es una característica humana común que puede ocurrir en diferentes niveles, originarse por factores genéticos, ser causada por traumas o mordida cruzada como resultado o discapacidad muscular. El objetivo de este estudio fue evaluar la relación entre la mordida cruzada posterior, desviación de la línea mediana y asimetría facial. Fueron evaluados 70 niños entre 3 y 10 años de edad mediante examen clínico y fotográfico. Utilizando Microsoft Power Point Office 2007, se dibujaron líneas horizontales y una línea vertical en la línea mediana, para analizar subjetivamente las diferencias faciales. En relación con el resalte, la mayoría de los niños $(78,6 \%)$ mostró relación normal, seguido por un resalte aumentado $(17,1 \%)$ y mordida cruzada anterior $(4,3 \%)$. En relación con la sobremordida, la mayoría de los niños $(60 \%)$ mostró relación normal, $27,1 \%$ una mordida abierta anterior (sobremordida negativa) y 12,9\% mostró una sobremordida aumentada. La mordida cruzada posterior estuvo presente en $27,1 \%$ de los niños. Entre ellos, el $68,4 \%$ presentaba mordida cruzada unilateral del lado derecho, $21,1 \%$ mordida cruzada bilateral y el $10,5 \%$ mordida cruzada unilateral en el lado izquierdo. No hubo asociación estadísticamente significativa entre la mordida cruzada posterior y asimetría facial según la prueba exacta de Fisher $(p=0,0970)$. En relación a la línea mediana, se observo una asociación estadísticamente significativa entre mordida cruzada posterior $(p=0,0109)$ y asimetría facial $(p=0,0310)$. Existe asociación entre la mordida cruzada posterior y la desviación de línea mediana. No hubo asociación entre la mordida cruzada posterior y asimetría facial.

PALABRAS CLAVE: asimetría facial, mordida cruzada, maloclusión, ortodoncia.

\section{REFERENCES}

Almeida, M. A. O.; Quintão, C. C. A; Brunharo, I. H. P. V.; Koo, D. \& Coutinho, B. R. Does the correction of a functional posterior unilateral crossbite improve the facial asymmetry? Rev. Dent. Press Ortodon. Ortop. Facial, 14(2):89-94, 2009.

Bardinet, E.; Baron, P.; Bazert, C.; Boileau, M. J.; Bougues, S. R.; De Brondeau, F.; Darqué, F.; Faure, J.; Gardes, C.; Garnier, E.; Milheau, J. F.; Nakache, C.; Pujol, A. \& Treil, J. Approche orthodontique à l'asymétrie. Orthod. Fr., 73(3):243-315, 2002.

Baume, L. J. Physiologic tooth migration and its significance for the development of occlusion. II The biogenesis of accessional dentition. J. Dent. Res., 29(3):331-7, 1950.

Castelo, P. M.; Pereira, L. J.; Andrade, A. S.; Marquezin, M. C. \& Gavião, M. B. Evaluation of facial asymmetry and masticatory muscle thickness in children with normal occlusion and functional posterior crossbite. Minerva Stomatol., 59(7-8):423-30, 2010.

Dalla-Bona, D. A.; Matsumoto, E.; Tanaka, E. \& Tanne, K. Tratamento ortognático de um paciente com assimetria mandibular severa e disfunção dos músculos mastigatórios: Relato de um caso clínico. Rev. Fac. Odont. Porto Alegre, 46(1):80-9, 2005.

Domiciano, A. M. O.; Nunes, K. J. \& Zacardi, C. V. H. Mordida cruzada e sua relação com a assimetria de ombro. Rev. Saude Pesqui., 3(3):329-37, 2010.

Gazit-rappaport, T.; Gazit, E. \& Weinreb, M. Quantitative evaluation of lip symmetry in skeletal asymmetry. Eur. J. Orthod., 29(4):345-9, 2007.

Gazit-Rappaport, T.; Weinreb, M. \& Gazit, E. Quantitative evaluation of lip symmetry in functional asymmetry. Eur. J. Orthod., 25(5):443-50, 2003.

Gonçalves, P. E.; Garbin, C. A. S.; Garbin, A. J. I. \& Pavan, A. F. G. Aspectos socioeconomicos versus hábitos bucais deletérios: análise de uma relação causal. Rev. Fac. Odontol. Lins, 19(2):13-8, 2007.

Good, S.; Edler, R.; Wertheim, D. \& Greenhill, D. A computerized photographic assessment of the relationship between skeletal discrepancy and mandibular outline asymmetry. Eur. J. Orthod., 28(2):97102,2006 . 
SANTOS, R. R.; GARBIN, A. J. I.; SALIBA, O. \& GARBIN, C. A. S. Analysis of association between posterior crossbite, median line deviation and facial asymmetry. Int. J. Odontostomat., 8(1):93-97, 2014

Gribel, M. N. Tratamento de mordidas cruzadas unilaterais posteriores com desvio. Dental Press J. Orthod., 4(5):4754, 1999.

Guyuron, B. Combined maxillary and mandibular osteotomies. Clin. Plast. Surg., 16(4):795-801, 1989.

Kataoka, D. Y.; Scavone Junior, H.; Vellini-Ferreira, F.; CotrimFerreira, F. A. \& Sato, V. Study of the anteroposterior relationship between deciduous dental arches of Japanese-Brazilian children, from 2 to 6 years of age. Rev. Dent. Press Ortodon. Ortop. Facial, 11(5):83-92, 2006.

Macena, M. C.; Katz, C. R. \& Rosenblatt, A. Prevalence of a posterior crossbite and sucking habits in Brazilian children aged 18-59 months. Eur. J. Orthod., 31(4):357-61, 2009.

Martins, R. J.; Fortes, F. D. S.; Garbin, C. A. S.; Moimaz, S. A. S. \& Saliba, N. A. Relação entre hábitos de sucção não-nutritiva e mordida aberta anterior. J. Health Sci. Inst., 21(4):401-4, 2003

Oliveira, C. M. Maloclusão no contexto da saúde pública. In: Bonecker, M. \& Sheiham, A. Promovendo saúde bucal na infância e adolescência. São Paulo, Santos, 2004.

Primozic, M. O.; Ovsenik, M.; Richmond, S.; Kau, C. H. \& Zhurov, A. Early crossbite correction: a three-dimensional evaluation. Eur. J. Orthod., 31(4):352-6, 2009.

Proffit, W. R.; Phillips, C. \& Sarver, D. M. Contemporary treatment of dentofacial deformity. St. Louis, Mosby, 2003.

Shimazaki, T.; Motoyoshi, M.; Hosoi, K. \& Namura, S. The effect of occlusal alteration and masticatory imbalanceon the cervical spine. Eur. J. Orthod., 25(5):457-63, 2003.
Correspondence to:

Univ. Estadual Paulista

Araçatuba Dental School

José Bonifácio, 1193

16015-050

Araçatuba - SP

BRAZIL

Email: renatar.santos@yahoo.com.br

Received: 24-08-2013

Accepted: 11-11-2013 